\title{
オオムギ黄萎ウイルスの純化および血清学的診断
}

\author{
宇杉 富雄・中野 正明 - 新海昭 ${ }^{1)}$ \\ (九州農業試験場)
}

\section{Purification and serological diagnosis of barley yellow dwarf virus.}

Tomio Usugi, Masaaki NAKANo and Akira Shinkai (Kyushu National Agiricultural Experiment Station, Chikugo, Fukuoka 833)

\begin{abstract}
Barley yellow dwarf virus (BYDV), occurring in Kyushu, was purified and the antiserum against BYDV was prepared. The antiserum reacted with BYDV up to a dilution of $1 / 160$ in precipitin ring interface test. Using this antiserum, the serological diagnosis of BYDV by ELISA was developed. BYDV in the leaf extract of infected barley plants could be detected up to a dilution of $1 / 640$ by ELISA. Concentration of BYDV in barley plants showing yellow symptoms was higher in the upper to middle leaves than in the lower leaves. BYDV was frequently detected in barley and wheat plants showing yellow symptoms in the fields of Kyushu National Agricultural Eperiment Station.
\end{abstract}

前報 ${ }^{5}$ において九州農試围場，諫早市および八女市の 農家固場の黄化症状のムギ類から barley yellow dwarf virus（オオムギ黄萎ウイルス ${ }^{2 i}=\mathrm{BYDV}$ )およびコムギ 黄葉ウイルス (WYLV) が分離されることを報告した。 これらのウイルスの検定を病徴と電顕観察により行って いるが，迅速且っ正確に検定することは困難であり，簡 易検定法の確立が必要となった。

そこで筆者らはBYDVの抗血清を作製し，酵素結合 抗体法 (ELISA) による血清学的診断法を確立した。こ こにその結果を報告する。

\section{材料および方法}

供試 BYDVは黄化症状を呈したコムギ株より分離し たものであり ，ムギクビレアブラムシによりオオムギ (西海皮 1 号) に継代接種したものである。ウイルスの 增殖はすべてオ才ムギ（西海皮 1 号）を用い，網室内で 行った。 $\gamma$ ーグロブリン，アルカリフォスファターゼ結 合抗体 (conjugate) の作製およびELISAの実施方法は, すべてClark and, Adams (1977)"に従った。

1）現在 日本植物防疫協会

\section{試験結果 \\ 1.BYDVの純化および抗血清の作製}

Matsubara らの純化法”に従い，本ウイルスの純化老 試みたところ，ほとんどウイルスが得られなかった。そ こで，各種の検討を行い，第 1 図に示した純化法を確立 した。Matsubara らの純化法と異なるところは，クエ ン酸緩衝液を使用したことおよび四塩化炭素，エチルエ ーテルによる処理を行ったことである。しょ糖密度勾配 遠心後, 本ウイルスは単一のピークとして認められた（ 第2図)。冬期に採取した純化材料からは，その他の時 期に採取したものより多くのウイルス量を得ることがで きた。得られた純化䅺品を $2 \%$ PTA で染色し電顕観察 したところ直径 28-30nmの球状粒子が多く認められたが， 中には若干崩壊した粒子も観察された（第３図）。

純化ウイルス標品をアジュバント法により家兔に5回 注射し，抗血清を作製した。得られた抗血清はリングテ ストで本ウイルスと 160 倍希勫まで反応したが, 健全植 物成分とは反応しなかった。

2. ELISAによるBYDVの検出 オオムギ感染葉の0.02M リン酸緩衝生理食塩水(0.05 
\% Tween 20を含む, PBS一T) による20倍粗汁液を用 いて ELISAを行い，作製した $\gamma$ ーグロブリンおよび conjugateの最適濃度を調べた。その結果， $\gamma$ ーグロブリ ンおよび conjugate の濃度をそれぞれ1,600倍及び3,200 倍にした場合においても十分に強い発色が認められた。 一方, 健全植物汁液ではほとんど発色が認められなかっ た。従って以下の試験はこの条件で行った。

オオムギ感染葉粗汁液を PBS一Tで段階希釈し, 本

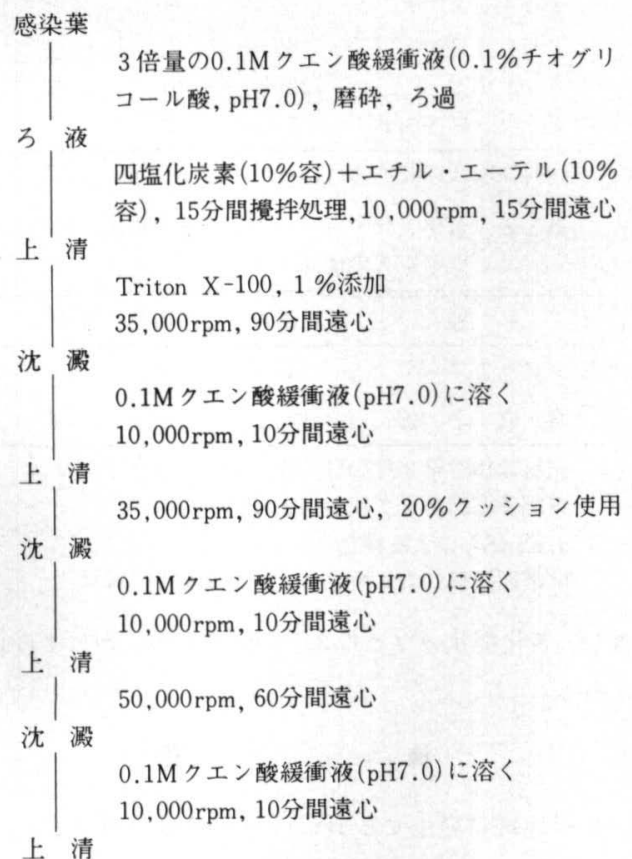

10 40\%しょ糖密度勾配遠心， $38,000 \mathrm{rpm，}$ 60 分間, ISCO fractionator で分取

第1図オオムギ黄萎ウイルス(BYDV)の純化法

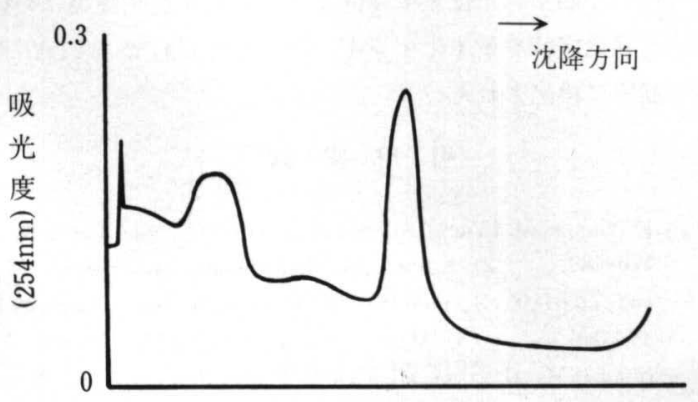

沈降 距離

第 2 図 部分純化標品のしょ糖密度勾配遠心図 (38,000rpm,60分間遠心) 感染葉 $150 \mathrm{~g}$ より純化
ウイルスの粗汁液中における検出限界濃度を求めたとこ ろ，本ウイルスはおよそ 640 倍まで検出されることが明 らかになった(第4図)。

接種後 5 カ月を経たオオムギから全葉を採取し, 各葉 位におけるウイルス濃度を調べた。その結果，止葉～上 位葉は無症状であったが, 高い発色值が得られた。中位 葉は葉先が黄化していたが, 上位葉と同程度あるいはや や弱い発色が認められた。下位葉は黄白色化, あるいは 葉先が枯死しており発色は極めて弱かった（第 1 表）。
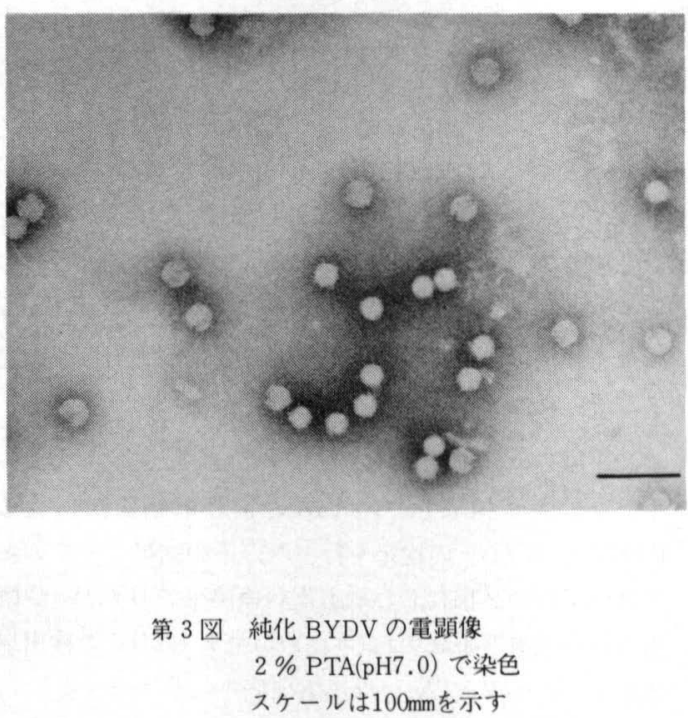
スケールは $100 \mathrm{~mm}$ を示す

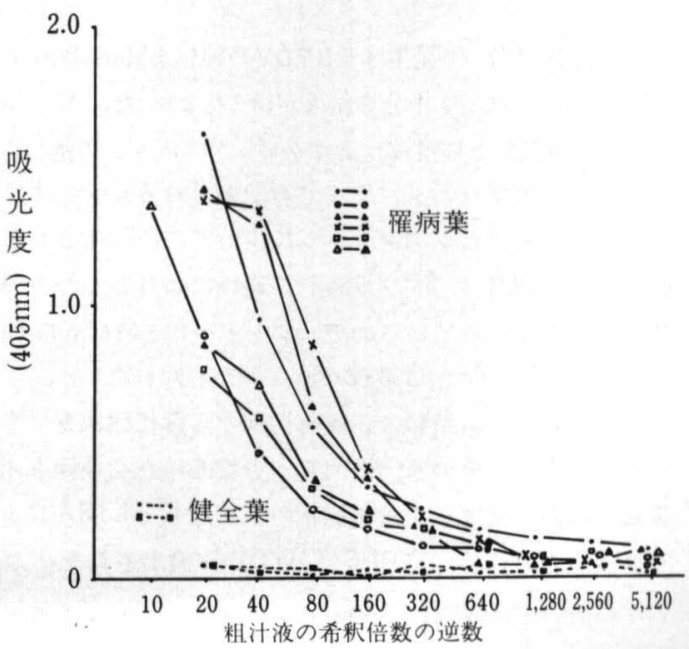

第 4 図BYDV 感染葉粗汁液の希釈度と発色程度 オオムギ(西海皮 1 号)，1,600倍の $\gamma$ グロブリン，3,200倍の conjugate 使用 
第1表 BYDV 感染才オムギ(西海皮 1 号)の各葉位 におけるウイルス濃度

\begin{tabular}{|c|c|c|c|c|}
\hline $\begin{array}{l}\text { 試料 } \\
\text { 番号 }\end{array}$ & 葉 & 位 & 佂 & $\begin{array}{c}\text { 吸光度 } \\
(405 \mathrm{~nm})\end{array}$ \\
\hline \multirow{8}{*}{1} & \multicolumn{2}{|l|}{ 止葉 } & 無 症 状 & 1.45 \\
\hline & \multicolumn{2}{|c|}{ 止葉より 1 葉目 } & 無 症 状 & 1.35 \\
\hline & & 2 & 無 症 状 & 1.17 \\
\hline & & 3 & 葉先わずかに黄化 & 1.29 \\
\hline & & 4 & 葉先わずかに黄化 & 1.20 \\
\hline & & 5 & 葉先黄化 & 0.55 \\
\hline & & 6 & 全征黄化 & 0.46 \\
\hline & & 7 & 葉先枯死 & 0.47 \\
\hline \multirow{8}{*}{2} & \multicolumn{2}{|l|}{ 止葉 } & \multicolumn{2}{|l|}{ 無 症 状 } \\
\hline & \multicolumn{2}{|c|}{ 止葉より 1 葉目 } & \multicolumn{2}{|l|}{ 無 症 状 } \\
\hline & & 2 & \multicolumn{2}{|l|}{ 無 症 状 } \\
\hline & & 3 & 無 症 状 & 1.25 \\
\hline & & 4 & 葉先わずかに黄化 & 1.01 \\
\hline & & 5 & 葉先 黄化 & 0.73 \\
\hline & & 6 & 全葉黄化 & 0.34 \\
\hline & & 7 & 全葉黄白色化 & 0.17 \\
\hline
\end{tabular}

PBS - Tによる20倍希釈粗汁液を抗原として使用。

1,600倍 $\gamma$-グロブリン，3，200倍 conjugate 使用

また，接種後 1 カ月を経たオオムギを用いても同様の結 果が得られた。

1987年春，九州费試图場加黄化症状を呈する才オム ギ、コムギを採取し，ELISAおよび電顕観察による BYDVとWYLVの検定を行った。その結果，才オムギ ではいずれの品種においても高い検出率でBYDVが検 出された（第 2 表）。コムギにおいても BYDVの検出率 は高かったがWYLVの検出率は低かった（第 3 表）。

\section{考}

\section{察}

九州地区において発生するBYDVの純化をMatsubaraら の方法3で行ったが, 十分な結果が得られなかった。 Matsubaraらが供試したBYDVはムギクビレアブラムシの他にム ギとゲナガアブラムシによっても伝搬されるが2.4，本ウ イルスはムギクビレアブラムシによってのみ伝搬される。 BYDVには媒体するアブラムシの違いによりいくつか系 統の存在が知られているので, 本ウイルスとMatsubara らが用いたBYDVとは系統が違うのかも知れない。

九州地域でのムギ類は, 成熟初期から黄化症状を呈す ることが多く，その原因は明らかでなかった。今回九州 農試圃場内で発生した黄化症状のムギ類をELISAによ り調査したところ, 高頻度でBYDVが検出された。コ ムギにおいては WYLV が検出されたが，その検出頻度 は低かった。これらの結果は, BYDV が黄化症状の原因 の一つであることを示している。今後，WYLVの簡易 検定法を確立し，BYDVおよびWYLVの発生状況を調
第 2 表 黄化症状を呈する二条才オムギのELISA による BYDV 検定

\begin{tabular}{|c|c|c|c|}
\hline \multirow{2}{*}{ 品 種 名 } & \multirow{2}{*}{$\begin{array}{c}\text { 试料総数 } \\
\text {. }\end{array}$} & \multicolumn{2}{|c|}{ 検定結果 } \\
\hline & & 陽 性 & 陰 性 \\
\hline ふじ二条 & 6 & 5 & 1 \\
\hline あまぎ二条 & 4 & 3 & 1 \\
\hline はるな二条 & 4 & 4 & 0 \\
\hline カワサイゴク & 6 & 6 & 0 \\
\hline さつき二条 & 10 & 10 & 0 \\
\hline イシュクシラズ & 14 & 12 & 2 \\
\hline カワミズキ & 7 & 7 & 0 \\
\hline アサヒ 5 号 & 9 & 7 & 2 \\
\hline カワホナミ & 12 & 10 & 2 \\
\hline ダイセンゴールド & 5 & 5 & 0 \\
\hline
\end{tabular}

試料採取は1987年 4 月13日

第3表 黄化症状を呈するコムギから検出された ウイルスの種類

\begin{tabular}{cccc}
\hline \hline 品 種 & 試料総数 & BYDV $^{a)}$ & WYLV $^{b /}$ \\
\hline シロガネコムギ & 4 & 4 & 0 \\
育 成 系 統 & 17 & 14 & 4 \\
\hline
\end{tabular}

試料は1987年2月20日採取，育成系統は全てコム ギ縞萎縮病，么ギ類萎縮病に抵抗性。

a)ELISAによる検定

b)電㩆観察による検定，コムギ黄葉ウイルス

查し，黄化症状とウイルスとの関連明らかにする必要 がある。

摘 要

九州地域に発生するBYDVの純化法を確立し，抗血 清を作製した。得られた抗血清は本ウイルスとリングテ ストで160倍まで反応した。本抗血清を用い，EＬIS A による血清学的彰断法を開発した。本法によりオオムギ 感染葉粗汁液中のウイルスは 640 倍希积まで検出された。 黄化症状株のオオムギ葉における BYDV 濃度は上〜中 位葉で高く，下位葉では低かった。九州農試围場におい て黄化症状を示すオオムギ，コムギ株からはBYDY が 高率に検出された。

\section{引用 文 献}

1) Clark, M. F. and Adams, A. N. (1977) J. gen. Virol. 34 : 476-483. 2) Kojima. M., Matsubara, A., Yanase, S. and Toriyama. S. (1983) Ann. Phytopath. Soc. Japan 49: 338-346. 3) Matsubara, A., Kojima. M., Kawano, S., Narita, M., Hattori, M., Uyeda. I. and Shikata, E. (1985) Ann. phytopath. Soc. Japan $51: 152-158$. 4) 新津純一 ・高橋 亘・小岛 誠 (1987) 日植病報 53:424. 5) 宇 杉富雄 - 中野正明 - 新海 昭 (1987) 九㖞虫研会報 $33: 21$ -23 .

(1988年 4 月30日＼cjkstart受領) 